\title{
The LRA and Its Costs on Economic Security in Gulu District, Northern Uganda
}

\author{
Anne Abaho, Solomon Asiimwe, Micheal Mawa \\ Nkumba University, Entebbe, Uganda \\ Email: aabaho@nkumbauniversity.ac.ug
}

How to cite this paper: Abaho, A., Asiimwe, S. and Mawa, M. (2019) The LRA and Its Costs on Economic Security in Gulu District, Northern Uganda. Open Journal of Social Sciences, 7, 133-146. https://doi.org/10.4236/jss.2019.711011

Received: September 6, 2019

Accepted: November 17, 2019

Published: November 20, 2019

Copyright (c) 2019 by author(s) and Scientific Research Publishing Inc. This work is licensed under the Creative Commons Attribution International License (CC BY 4.0).

http://creativecommons.org/licenses/by/4.0/

\section{(c) (i) Open Access}

\begin{abstract}
The study acknowledged economic security as part of the wider security conceptions especially in human security. Using the case of the Lord's Resistance Army (LRA), the study brought to light the costs of conflict on economic security particularly in Gulu district, Northern Uganda. It adopted a qualitative approach and relied on primary data collection methods (Interviews, Focus Group Discussions and observation) to assess how conflict affected economic security. Field findings revealed that the conflict had tremendous effects on economic security ranging from destruction of property and loss of assets, reduction in production and persistent poverty among others. The study recommended that the government should deliberately target the most vulnerable groups for training and skilling as well as capitalization of income generating projects.
\end{abstract}

\section{Keywords}

Security, Economic Security, Lord's Resistance Army (LRA), Gulu District

\section{Introduction}

The objective of the study was to; assess the economic insecurities resulting from the LRA conflict in Gulu District, Northern Uganda. Conflict poses serious challenges at all levels-from individual to collective compromising the chances of achieving political, social and economic stability [1]. [1] explains the size of the problem in statistical forms indicating that about 191 million people lost their lives to political violence in the 20th century and since the turn of the century, about 4 million have died in armed conflict [1]. In 2008, the United Nations Development Program (UNDP) confirmed that conflict has devastating consequences; creates large numbers of casualties either directly or indirectly, exacerbates malnutrition and disease, substantially leads to loss of livelihood, 
employment and incomes, collapses infrastructure, State institutions and rule of law as well as maintaining a chain of insecurity and fractured social networks [2] [3]. These consequences have serious implications on both State and human security.

The idea of security has evolved over the centuries. Security in the traditional sense, following the 1648 Treaty of Westphalia, that brought into existence the modern-day State, was conceived of as consisting in the use of military power to protect the State from external threats [4]. This view, which dominated the security discourse for centuries was drumbeat by radical, classical and neo-realists such as Hobbes, Morgenthau, Waltz and Kissinger who contended that the referent object of security is the state, and that the state and the military are the means to achieve maximum security in an anarchical world [5]. Security was seen this way because the major threats to the survival of States were conceived of as external.

Nonetheless, by the middle of the twentieth century inter-state conflicts had begun to cede ground to intra-state conflicts, beginning with the wars of independence especially in Africa, and in the post-independence era during which civil wars became rampant in the newly independent states. The internal wars were shaped by the colonial maltreatment of colonised peoples and the political and economic mismanagement of newly independent states by native leaders who inherited post-colonial states. Following the end of the Cold War in 1991, insecurity continued to come more from within than from without the State threatening the internal socio-political, economic, environmental, and social stability of the occupants of the State [6]. These threats affected not just the existence of a State, but also the security of the human person. Otherwise stated, they are human security threats.

Human security encompasses all things that eliminate threats to a person including those that cause; fear, want and indignity [7]. It therefore constitutes part of the larger security discourse that includes food, health, environmental, personal, political, community, and economic security. The United Nations Trust Fund for Human Security [8] listed persistent poverty and unemployment among others as indicators of economic insecurity. Governments are obliged to, in the human security view, ensure the satisfaction of these aspects of human security, and when a disaffection or discontent occurs that arises from any or several of these aspects, the duty of a government is to respond by addressing them instead of resorting to the use of military force, which, overtime has proved to be incompetent in providing lasting solutions to insecurity [9].

\subsection{The History of the LRA Conflict}

The story of the LRA, according to [10] begun with Alice Lakwena, a mad woman from the Village of Opit in Northern Uganda who, claiming that God had appealed to her to purify the North and later the world through combat defended war as divine. Fisher documented that emerging as an insurgent leader 
under the Holy Spirit Mobile Forces (HSMF) on August 20th 1986, Lakwena mobilized 150 men with 40 guns and marched towards the barracks in which Government soldiers were said to have kidnapped and detained young people from her town. Unfortunately, Lakwena was defeated by the Government forces but Joseph Kony carried on the struggle under the Lord's Resistance Army. A cousin to Lakwena from the village of Odek, Kony is said to have initiated the insurgency at the age of 26 [11]. It is documented that Joseph Kony formed the LRA in 1987 mainly to overthrow the Western Uganda dominated government of President Museveni [12]. [13] elucidated that the formation of the LRA was in response to the anti-government movement that emerged in the 1980s after Yoweri Museveni's overthrow of the Tito Okello regime, an ethnic Acholi from Northern Uganda.

During the LRA conflict that was prosecuted from majorly areas that constitute Northern Uganda, including Gulu District, between 1986 and 2006, the economic life of the people was brought to grinding halt. The war effort discouraged investment and hurt employment in effect. It impacted people's ability to cultivate their fields and to grow their food-hence killing both the people's source of income and livelihood. Many people of productive ages were abducted, killed or conscripted into the rebel ranks, and in the process denying them and their families the opportunity to build their economic life.

\subsection{Statement of the Problem}

Although the LRA was technically defeated and extinguished out of Uganda in 2006, and an economic recovery effort undertaken by the government of Uganda thereafter, under several programmes such as the Northern Uganda Social Action Fund (NUSAF); Peace, Recovery and Development Plan (PRDP), the legacies of the conflict are still economically felt by the people to date. These among others include; destruction of livelihoods and other assets, markets, damage to investment opportunities and loss of productive labour among others. These features of economic insecurity were captured by [14], that indicated that 43 percent of the population in Northern Uganda were poor compared to 4.7 percent in central Uganda, 24.5 in Eastern and 8.7 in Western Uganda. Similarly, a study by [15] and a report by [14], separately indicated, in 2015 and 2014, respectively, that the Youth in Northern Uganda grappled and were beset in their economic lives by low education levels, high poverty and unemployment compared to their counterparts in other parts of the country [14] [15]. Against the glaring statistical presentations above, this work sought to assess how conflict affects economic security with particular emphasis on the LRA conflict in Gulu District.

\section{Literature Review}

Conflict damages infrastructure, institutions and production, destroys assets, breaks up communities and networks as it kills and maims those engaged in and 
those caught up by it [15]. These givens have been captured in many and various bodies of literature. What is not obvious, as [15] has observed, is how these may have lasting economic effects over time. Below is a review of affiliated literature on how the economic insecurities resulting from conflict survive way beyond the cessation of hostilities.

\subsection{Persistent Poverty}

[16] elucidated that when conflicts and civil wars occur, they cause persistent poverty due to damaging infrastructure, production, assets and maiming of people. In support of Collier is a large body of literature [2], [17] and [18] that has elaborated on incidences whereby poverty has persisted beyond the cessation of fire, even with tremendous aid, economic recovery and reconstruction programmes aimed at easing or lifting the victims of the conflict out of poverty in its wake. Indeed, as [19] noted, in post-war Acholi, women took advantage of the shifted power relations to improve their economic status while men became disempowered. Thus, while some people in post-conflict period manage to take advantage of the new opportunities such as post-conflict recovery and reconstruction initiatives and programmes and manage to emerge out of poverty, there are those who remain chronically poor. These (chronically poor) are the category whom [15] defined as "those who either experience extended duration of poverty, or those who benefit the least andl or suffer most from contemporary development policies and practices, and for whom emergence from poverty is most difficult" [15].

Fortunately, there is normally an influx of foreign aid that follows the cessation of a conflict, which also avails opportunities for poverty reduction [20]. The authors [20] explained that in cases where economic growth is spurred after a conflict, it can be rapid, for instance, when farms and enterprises restart themselves and the reconnection of rural markets and towns create national and regional food markets to move food to deficit areas. Nonetheless, as [21] observed, economic recovery should not be left in the hands of private individuals for they are driven by profits and will immediately close should the profit-making opportunities narrow.

In the post-conflict environment, the recovery needs are not only overwhelming but there is equal pressure to kick-start the economy. Putting emphasis on economic recovery was recommended by [20] in 2009 because of its inextricable connection to employment and income generation as well as easing reintegration. Amidst the pressure though is the temptation to ignore or to overlook the needs of chronically poor people as leaders struggle to get on a good footing by pacifying potential "spoilers" [20]. Thus, in such an environment, focus may be directed towards groups seen as constituting a security threat (ex-combatants for example) at the expense of those that are perceived as less likely to pose a threat, such as women, young children, and the elderly, who unfortunately, constitute the chronically poor. 
Given the links between chronic poverty and conflict, such a focus would have significant positive implications for security and stability in the medium to long-term. Basic service provision aimed at the poorest and hard to reach, infrastructure to remote areas, and social protection transfers can help stimulate wider growth, ensure basic standards of living, increase economic security [20]. In the literature [18] [21] [22] [23] on recovery and reconstruction efforts in Northern Uganda following the end of the conflict, there is no indication that the most vulnerable groups or the chronically poor categories of society were deliberately targeted by the interventions, a miss which might partly or wholly explain persistent poverty.

\subsection{Unemployment}

Employment is most likely to be affected by war, not only during but also its aftermath. It goes without saying that a conflict environment does not facilitate production and heightens therefore the levels of unemployment. This is largely attributed to prolonged conflict periods during which school-age going children and youths lose out on education [18]. In the post-conflict environment, such groups bear no skills upon which they can seek employment. Undeniable, conflicts have negative impacts on educational attainments. For instance, study [24] found that a reduction in girls' education was registered following the Tajikistan civil war in the early 1990s, but the same had no impact on boys' education, because of the fact that households invested more on the education of male children after the war as a means to returning to their longer-term income levels than on females. This notwithstanding, [15] confirmed that difficulties in employability are caused by lack of appropriate skills needed to pursue employment. For instance, in Bosnia, displaced Bosnians during the 1992-95 war, were less likely to work in the post-conflict period [25]. This is likely especially if many people missed skilling opportunities on account of war, especially a protracted one. In Northern Uganda, a study by [26] indicated that only $54.8 \%$ were able to access economic opportunities.

Unfortunately, conflict, significantly affects investor confidence. It is prudent to submit that when investors lose confidence, investments will be discouraged and employment opportunities diminish. [2] explained that when investors perceive risks, they delay entry in post-conflict environments. The Program cited the example of investors delaying long term investment in production until they are assured of a country's stability. This narrative is equally confirmed in other literature [17]; [27] among others. For example, [17] noted that investors are wary of coming to countries where they and their investments are unsafe. Referring to the Boko Haram, [27] explained how Nigeria has suffered reduction in investors because of the insurgency related activities. In Northern Uganda, [28] listed loss of investment opportunities and resultant heightened unemployment levels as one of the costs of the conflict.

Luckily, investor confidence can be erected if security is restored to a degree that investors feel confident to re/establish their ventures and necessary infra- 
structure put in place to support production and marketing. Investor confidence can also be restored if recovery and development programmes in conflict ravaged areas provide, in addition to security and infrastructure, attractive incentives for investment in such areas. Skilling programmes can also be undertaken to equip war affected people and prepare them to take up job opportunities. Despite these initiatives evidence in Northern Uganda suggests that unemployment remains high at $32.5 \%$ way above the national poverty percentage of $19.7 \%$ [29].

\subsection{Damage to Capital}

Capital, both human and physical are important ingredients in dispelling economic insecurity, but are vulnerable during war time. Conflicts, according to [2] divert resources from production to destruction and its economic legacy is seen in capital flight and the destruction of assets and a corresponding reduction in economic production [2]. Confirming the UNDP view, [21] listed poverty and displacement, losses due to cattle raiding, loss of productivity, the impact of HIV/AIDS and loss of regional opportunity and trade as the socio-economic implications of the conflict. [21] further narrated that the agricultural production was undermined due to population displacement and land mines and the region bears the highest number of people not expected to live beyond 40 years.

There are arguments however that the impact of conflict on the economy is majorly dependent on the kind of capital that is destroyed. For example [17], using the growth model argued that if human capital is destroyed and not physical capital, recovery is slower due to the higher adjustment costs. The conflict in Northern Uganda as already indicated did not only lead to human capital destruction but also damaging of physical infrastructure. The more than 20 year war certainly reduced production and lowered economic performance. This work argues that economic growth (although alone insufficient) can avert the risk of conflict through employment generation. This is so because unemployed youths are highly vulnerable to recruitment thus, when the economy is destroyed, chances for increasing the available numbers for recruitment do not only increase but they may also become wider in post-conflict situation as the economy takes long to recover. This situation is certainly risky as the community can easily relapse into violence.

This section has discussed literature in light of the indicators of economic insecurity as identified by the UNTFHS. In the discussion, emphasis has been laid on how conflict causes and worsens these insecurities and therefore challenges the capacity of the survivors to rebuild their lives. Notable, the discussion has focused on the resultant unemployment, capital flight and damage to infrastructure. In the next section, a description of methods in studying the costs of conflict on economic security is undertaken.

\section{Methodology}

Borrowing from the non-positivism paradigm, the study is grounded in the phi- 
losophy of realism. Non-positivism is different from Comte's positivist research orientation in a manner that the latter believes in scientific research structure as more dependable in arriving at the truth [30]. The former however believes in the observable world, interacting with study subjects and approaching the research problem with a subjective view as opposed to positivism that considers objectivity in research. From the features of non-positivism as a research paradigm, the researcher opted for realism as the guiding research philosophy. According to [31], using the realist philosophy allows the researcher to make credible observations in for example single cases to determine causation without necessarily comparing situations. The study preferred a qualitative approach because it doesn't only allow an understanding of the meaning and nature of experiences of persons with different problems but it gives room to obtain intricate details about phenomena such as feelings, thought process and emotions that are difficult to extract or learn about through more conventional research methods [32].

This research opted for a case study-explanatory research design bearing in mind the nature of the research question [33]. This study sought to assess how the LRA conflict economic insecurity in Gulu district, Northern Uganda. As [34] explained, questions of how and why are more explanatory. The researcher found the case-study beneficial for it permitted an in-depth investigation of a problem without suffering the limitations of generalization that is common in quantitative studies. [35], in explaining the benefits of using a case-study design elucidated on how the researcher is able to make a conscious choice from a number of possible events, people and organizations among a large number of possibilities. Thus, the research chose Gulu district because of its crucial position during the LRA conflict. The district suffered attacks from the LRA and government counter attacks that in turn unleashed terror on the population but also had massive economic challenges. Using the non-probability sampling strategy, the study opted for Maximum Variation Sampling (MVS) under purposive sampling as often preferred in case studies [34]. The study areas included; Gulu Main, Lukodi and Awach Paibona in Gulu District. These were chosen based on their centraility during the conflict. For example, Gulu Main became the Centre of night commuters, Lukodi was attacked on $20^{\text {th }}$ May 2004 leading to the death of 64 people while Awach Paibona had the biggest camp, hosting Internally Displaced Persons (IDPs) from 4 parishes. A total of 44 participants (14 interviewees and 30 Focus Group Discussants) were involved in the study. The data collection methods were both primary (interviews, Focus Group Discussions (FGDs), observation) and secondary (document reviews). The research used Focus Group Discussion Guide, Interview Guide and Document Review checklist as the data collection instruments. The Focus Group Discussion Guide was mainly used to obtain data from the Returnees while the Interview Guide was beneficial in generating information from the key informants from key government offices such the Resident District Commissioner (RDC)'s office, the Chief Administrative Officer (CAO), the Northern Uganda Rehabilitation Program (NUREP) and 
social institutions such as the Acholi Religious Initiative and the Acholi Traditional leadership.

The Focus Group Discussion Guide was pre-tested on 4th May 2018 with 6 participants who had witnessed conflict. Equally, the instruments were reviewed by the researcher in line with the study objective. In equal measure, the International Health Sciences Research and Ethics Committee on 4th December approved the research instruments before final approval from the National Council for Science and Technology, a body in charge of all researches in Uganda.

The collected data were transcribed and organized according to themes. The work, as advised by [36] adopted thematic analysis as a common method of data analysis in descriptive qualitative studies. Hence, using the thematic analysis method, themes were identified, analysed and used in reporting the findings. This was arrived at after the researcher read and interpreted transcripts. Below is a discussion of the findings.

\section{Discussion of Findings}

\section{Introduction}

The economy is a significant aspect of security especially human security. Unfortunately, conflict does not only reduce the human capital of the affected area through death and disabilities (impacting on production thus) but it also impacts on the confidence of both internal and external investors in risking their investments in a conflict zone. The question posed was; how did conflict affect economic security as a human security dimension? Through the methods used, the conflict costs on economic security were gathered;

\section{1) Poverty}

Violent conflict, noted [2] worsens the array of traditional determinants of poverty such as livelihood destruction and thus limits future progress [18]. During the data collection process, the economic impact of conflict and the resultant poverty was evident in the responses from almost all categories of respondents. For example, in a FGD in Lukodi, a respondent intimated;

“...people have become poorer because property was destroyed... it is hard to get what to eat... many people have stopped thinking about tomorrow provided they can eat today... for some, it is as if the war will return, they are not sure... as you can see in town, the youth are redundant and they don't want to go to the villages, they don't have skills because they missed school... (FGD, 25th August, 2018).

It is worth acknowledging that poverty creates a dependent population that only survives on handouts. Indeed, as though confirming this view, R2 noted that;

"...in camps, people became dependent on handouts from the humanitarian organizations..." ....in IDP camps, apart from food distributed by the UN agencies, there was no other source of livelihood... many have even refused to leave the camps because they are not able to build their own lives like sustaining 
themselves with food... many were left there (in camps) because they were seen as a burden to their families... it is easier to access services in the camps, anyway (Interview, 27th August, 2018).

The war, according to R5, destroyed all sources of livelihood and people lost all on which they depended. As [9] and [37] on Human Development observed, the security of the individual is not simply about freedom from fear but also freedom from want. Poverty unfortunately widens the insecurity net by making it hard for people to purchase and economically command due to limited financial capacity. This incapacity however may as well be influenced by loss of property and asset destruction as below narrated.

2) Destruction of Assets and Property Loss

[2] and [21] confirmed that conflict destroys assets and hence causes rampant poverty. This view was expounded upon by a participant in a FGD in Lukodi who explained that;

"...the Acholis believed that I am a king in my home... but the war destroyed all we had.... we lost animals in addition to families... sometimes you feel like you are useless... you used to have but now you are helpless, you used to be productive, to feed your family, now you economically have nothing... we are hungry because the war destroyed our property..." (FGD, 25th August, 2018).

In the evening of 8th September 2018, as I met a FGD in AwachPaibona, a participant expressed related sentiments;

"... we returned from the camps with nothing... there was too much expectation but with nothing... the issue of land became serious, people are fighting.... even the dead may be angry we are not burying them properly because we used to burry on ancestral land... it is painful... with the conflict and displacement, traditional land boundaries were shifted... people are now fighting after returning..." (FGD, 25th August, 2018).

It should be noted as the [18] report did that property destruction during conflict and resultant poverty is a direct threat to future progress. Notable, ownership of property is not only a human right but it is also part of a widened component of security and safety needs. Hence, limitation of future opportunities for human survival by conflict is a direct threat to human security.

Similarly, in an interview with a respondent from Northern Uganda Rehabilitation Program (NUREP) he submitted while explaining the effect of conflict on economic security that; “...property was destroyed, livestock lost... everything was lost...". Interestingly, while people lament over poverty, Gulu's economy is not only fast growing but is also expensive. In submitting about the effect of the conflict on the economy, R6 confirmed that; "the war affected the economy of the area... prices are hiked, organizations hiked everything...". I later would taste the hiked prices when I journeyed to Gulu Main and Kirereno markets along Gulu-Kampala road during my observation exercise. It is worth recalling that as the literature [15] indicated, while the donors, investors and government may rush to boost the economy, this may be to the benefit of a few as the chronically poor may not necessarily benefit from the economic progress. 
[15]'s submissions were confirmed were confirmed during the observation exercise. As I walked into Gulu market, I was struck by the level of organization. The market boosts of well-arranged stalls that are categorized according to items/commodities under sale. I attempted to purchase a cluster of bananas at Ug shs. $6000=$ as the seller insisted on releasing it at Ug shs. $8000=$. Later, after my negotiating skills proved futile, I paid the expected figure. As I walked away, I kept wondering how the chronic poor (widows, children, elderly, physically handicapped) with no clear means of income and sources of livelihood survive. [38] reported that ten years after the war, the region bustles in trade and businesses shooting up after a renewed sense of optimism. This work argues that economic growth alone doesn't guarantee human security-the positivity in economic growth must be seen in the purchasing power and consumption abilities of those affected by conflict. The figure demonstrates the existence of markets and involvement of people in economic activities (Figure 1).

The captured photographic evidence paints a positive picture of a fast-growing economy. Indeed, as I stood before the stalls dealing in meat, I noticed that the difference between Gulu and Kampala (the capital city of Uganda) is only the name-this is actually Kampala in Gulu! Along the streets, the chains of supermarkets, fuel stations, banks, hotels, sports betting centers are manifest of a renewed life that the district is now enjoying.

\section{3) Reduction in Production}

The Northern region is economically known to have survived on agriculture and specifically; domestication of animals as well as cultivation of food crops [39]. The link between conflict and reduction in production has already been alluded to in the literature. Indeed, the LRA conflict did not affect the largest economic activity (agriculture) but also affected heavily food production. Production of food enhances the producer's monetary status while allowing him/her escape the net for want through consumption. [19] noted that the region is still
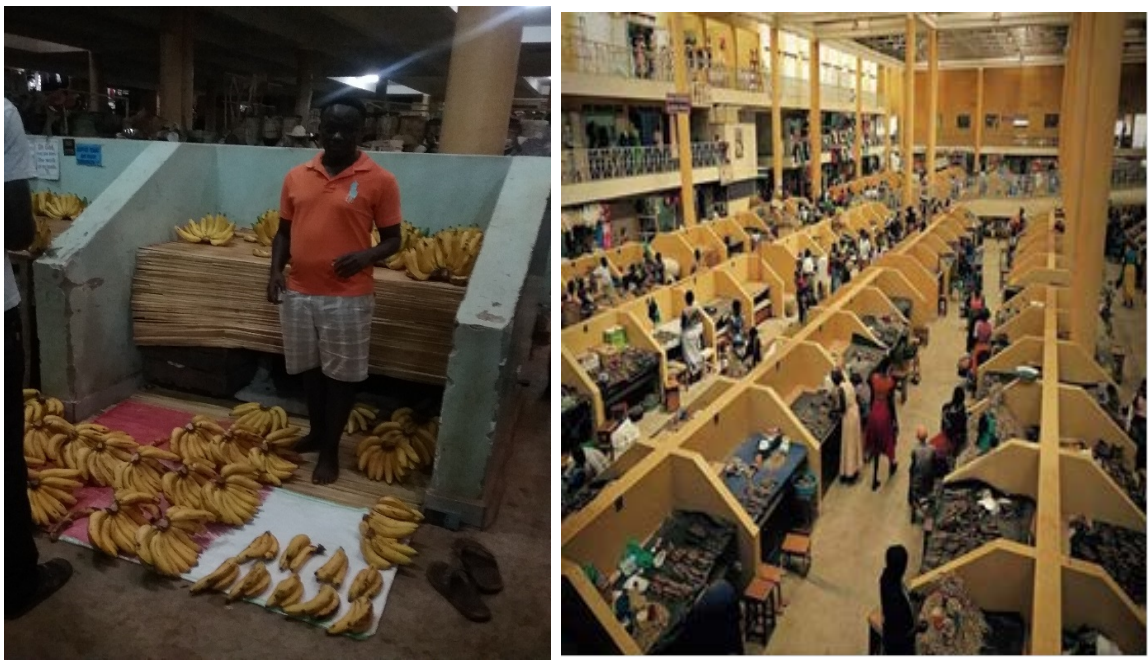

Figure 1. Images of Gulu Main Market. From Left: A vendor stands by his stall in the market, Right: The arrangement of stalls in Gulu Main Market. 
characterized by land wrangles and food insecurity. In a FGD in Gulu Main, a participant explained that;

"there are many cases of hunger and this is due to the violence... there is no farming because people, after the camps became very lazy... there are not willing to practice agriculture... Acholis used to do communal farming and were food secure... we had granaries...... due to the war, food reduced and we started eating food we didn't know... this has brought many problems, people are now falling sick..." (FGD, 25th August, 2018).

The effect of the conflict on production especially food production was also confirmed by the $\mathrm{R} 4$ respondent in an interview who explained that;

"...true, people did not want to go back due to land wrangles but the biggest challenge is food insecurity.... before the war, there were grannaries... women would open them with men's permission... now women despise men... there are high cases of food shortages... in the camps, you would not have access to the traditional foods like millet and peas but even now after return, people are still crying for food because they have no money... those in town have to buy food..." (Interview, 9th September, 2018).

While the conflict is reported to have affected production and affected food security, the reverse is true in Gulu town. Indeed, the markets beamed with all kinds of food stuffs. During the observation exercise, one could easily confuse the night for day. Along Gulu-Kampala Road, the street lights revealed the amounts of potatoes, rice, cassava, irish potatoes, fish and chicken among others. Young children walked from one side of the street to another carrying buckets of sim-sim in a struggle for potential customers. As I pondered within me why the respondents referred to food insecurity amidst plenty, I realized how afast-growing economy that is only afforded by a few must be further hurting the current population.

\section{Conclusion}

There is no doubt that the LRA conflict cost the Northern Uganda economy and Gulu District's economy, as empirical evidence and research findings have indicated in a number of ways that range from property destruction, persistent poverty, unemployment to reduction in production among others. It is hard to tell when these effects on the economy can be reversed but they will surely last many years after the guns were silenced. From the field findings, economic insecurity in Gulu is rife in ways that can be linked back to the conflict. To remedy the situation, there is need for the Government of Uganda to design empowerment program deliberately targeting the vulnerable groups in post-conflict Gulu district while sustaining economically empowering programs across the country to avert poverty. The over twenty years of the war did not only affect the sources of livelihood, degrade human and physical capital, and drive people out of meaningful economic production for a protracted period of time, but it also complicated many people's opportunities to live beyond the conflict by denying them formal education upon which employment is determined. Worst, because of the 
nature of the conflict, many people were left with physical disabilities that to date affect meaningful involvement in production. This however can be mitigated by deliberately targeting the most vulnerable populations such as widows, former child soldiers and orphan headed house-holds and giving them adequate training in enterprising activities. This will help improve their economic base while keeping them actively engaged in economically productive activities. Thus, training however can only carry meaning if sufficient financial services are extended to the beneficiaries.

\section{Conflicts of Interest}

The authors declare no conflicts of interest regarding the publication of this paper.

\section{References}

[1] Ferguson, N. (2010) Post-Conflict Reconstruction. Cambridge Scholars Publishing, New Castle.

[2] UNDP (2008) Post Conflict Economic Recovery: Enabling Local Ingenuity. Bureau for Crisis Prevention and Recovery, New York.

[3] David, C., et al. (2011) Post-Conflict Recovery: Institutions, Aid or Luck? IMF Working Paper, 1-34. https://doi.org/10.5089/9781455269471.001

[4] Asiimwe, S.M. (2017) Security Studies: Principles and Practices. Marko Mangheni Publishers, Kampala.

[5] Burchill, S., et al. (2005) Theories of International Relations. 3rd Edition, Palgrave Macmillan, Houndmills.

[6] Buzan, B. and Hansen, L. (2009) The Evolution of International Security Studies. Cambridge University Press, Cambridge. https://doi.org/10.1017/CBO9780511817762

[7] Mushasha, S. and Dear, L. (2010) Human Development Report 2009/10 (Occupied Palestinian Territory): Investing in Human Security for a Future State. UNDP, New York.

[8] United Nations Trust Fund for Human Security (n.d.) Human Security in Theory and Practice. United Nations, New York.

[9] CHS (2003) Human Security Now. UN, New York.

[10] Fisher, M. (2011) The Bizarre and Horrifying Story of the Lord's Resistance Army.

[11] Gersony, R. (1997) The Anguish of Northern Uganda: Results of a Field-Based Assessment of the Civil Conflicts in Northern Uganda. USAID Mission, Kampala.

[12] Conciliation-Resources (n.d.) History: The Lord's Resistance Army Conflict.

[13] Katine (2007) Background: The Lord's Resistance Army.

[14] Ministry of Finance Planning and Economic Development (2017) State of Uganda Population Report 2017. Transforming Uganda's Economy: Opportunities to Harness the Demographic Dividend for Sustainable Development. MFPED, Kampala.

[15] Okidi, J.A. and Mugambe, K.G. (2002) An Overview of Chronic Poverty and Development Policy in Uganda. Economic Policy Research Centre. PRC Working Paper 11 .

[16] Justino, P. (2014) Barriers to Education in Conflict-Affected Countries and Policy 
Opportunities. UNESCO Institute for Statistics, Motreal.

[17] Collier, P. (2009) Post-Conflict Recovery: How Should Strategies Be Distinctive. Journal of African Economies, 18, 99-131. https://doi.org/10.1093/jae/ejp006

[18] Serneels, P. and Verpooten, M. (2012) The Impact of Armed Conflict on Economic Performance: Evidence from Rwanda. Centre for the Study of African Economies. CSAE Working Paper WPS/2012-10.

[19] UNDP (2015) Uganda Human Development Report 2015: Unlocking the Development Potential of Northern Uganda. UNDP, Kampala.

[20] Addison, T., Bach, K. and Braunholtz-Speight, T. (2011) Violent Conflict and Chronic Poverty. In: Shepherd, A. and Brunt, J., Eds., Addressing Chronic Poverty, Palgrave McMillan, Basingstoke, 160-182.

[21] Ahikire, J., Madanda, A. and Ampaire, C. (2012) Post War Economic Opportunities in Northern Uganda: Implications for Women's Empowerment and Political Participation. International Alert, London.

[22] OPM (2007) Peace, Recovery and Development Plan for Northern Uganda (PRDP) 2007-2010.

[23] UNDESA (2009) United Nations Policy for Post-Conflict Employment Creation, Income Generation and Reintegration. UN, Geneva.

[24] Office of Prime Minister (2012) Peace Recovery and Development Plan-PRDP2. Grant Guidelines for Local Governments. OPM, Kampala.

[25] Bertasi, E. (2013) Post Conflict Reconstruction and Development: The PRDP for Northern Uganda. University of Tennessee, Tennessee.

[26] Shemyakina, O. (2006) The Effect of Armed Conflict on Accumulation of Schooling: Results from Tajikistan. HiCN Working Paper No. 12, Households in Conflict Network.

[27] Kondylis, F. (2007) Agricultural Outputs and Conflict Displacement: Evidence from a Policy Intervention in Rwanda. HiCN Working Paper No. 28, Households in Conflict Network.

[28] International-Alert (2012) Monitoring the Impact of the Peace Recovery and Development Plan on Peace and Conflict in Northern Uganda. International Alert, London.

[29] Omilusi, M. (2016) The Multi-Dimensional Impacts of Insurgency and Armed Conflict on Nigeria. Asian Journal of Social Sciences, Arts and Humanities, 4, 29-39.

[30] Ministry of Finance, Planning and Economic Develop, Office of Prime Minister and Office of President (2003) Post Conflict Reconstruction: The Case of Northern Uganda. Discussion Paper 7.

[31] Okoth, C. and Nabisubi, R. (2018) Poverty Levels in Northern Uganda Drop.

[32] Alessandrini, M. (n.d.) Non-Positivist Approaches to Research in the Third Sector: Empowered Policy Making. ISTR 10 th International Conference, Siena, Italy, 10-13 July, 2-17.

[33] Sayer, A. (1992) Method in Social Sciences: A Realist Approach. Routledge, London.

[34] Yin, K.R. (1994) Case Study Research: Design and Methods. 2nd Edition, Sage Publications, Thousand Oaks.

[35] Strauss, A. and Corbin, J. (1990) Basics of Qualitative Research: Techniques and Procedures for Developing Grounded Theory. 2nd Edition, Sage Publications, Thousand Oaks.

[36] Denscombe, M. (2010) The Good Research Guide for Small Scale Social Research 
Projects. 4th Edition, Open University Press, Berkshire.

[37] Flick, U. (2009) An Introduction to Qualitative Research. 4th Edition, Oliver's Yard, Sage Publications, London.

[38] Patton, Q.M. and Cochran, M. (2002) A Guide to Using Qualitative Research Methodology.

[39] UNDP (1994) Human Development Report: New Dimensions of Human Security. UNDP, New York. 